Article

\title{
Diasporic Civic Agency and Participation: Inclusive Policy-Making and Common Solutions in a Dutch Municipality
}

\author{
Antony Otieno Ong'ayo \\ ISS-International Institute of Social Studies, Erasmus University Rotterdam, 2518 AX The Hague, The Netherlands; \\ E-Mail: ongayo@iss.nl
}

Submitted: 27 July 2019 | Accepted: 21 October 2019 | Published: 28 November 2019

\begin{abstract}
With a growing presence in The Hague municipality, the sub-Sahara African diasporas like other minority groups face challenges related to integration, participation, representation, and social exclusion. The majority still find difficulties with the Dutch language, with access to education, the labour market, and public services. These concerns also inform initiatives by the municipality in search of joint solutions through citizen participation with the African diasporas. Equally, African diasporas engage in formal and informal initiatives targeting decision-maker in The Hague, seeking to reverse their sense of vulnerability and social exclusion in the city. Using data gathered through ethnographic fieldwork in The Hague from 2015 to 2017, this article examines how African diaspora organisations have sought to exercise their civic agency and to influence policy-making to become more inclusive, by proposing common solutions and collective initiatives. The aim is to understand how diaspora collective initiatives are informed by notions of civic agency, and how prospects can be generated for diasporas to secure the 'right to have rights' and ensure that the host municipality addresses concerns related to the diasporas' exclusion. The concept of civic agency is also used to analyse dynamics influencing diasporic activities, the broader context of diaspora engagement, and some likely socio-political outcomes. I argue that collective diasporic initiatives are broadly aimed at ensuring more inclusive policy-making and that solutions are an expression of diasporic people's collective energy and imagination. These collective initiatives demonstrate the significance of enacted citizenship in challenging broader conditions of social and economic exclusion that the African diasporas face in host municipalities like The Hague.
\end{abstract}

\section{Keywords}

citizenship; civic agency; collective initiatives; diaspora engagement; inclusive policy-making; The Hague

Issue

This article is part of the issue "Inclusion through Enacted Citizenship in Urban Spaces" edited by Rachel Kurian (Erasmus University Rotterdam, The Netherlands) and Helen Hintjens (Erasmus University Rotterdam, The Netherlands).

(C) 2019 by the author; licensee Cogitatio (Lisbon, Portugal). This article is licensed under a Creative Commons Attribution 4.0 International License (CC BY).

\section{Introduction}

With an increasingly multicultural population generated by international migration, municipalities in most European Union member states are confronted with the implications of what has been termed 'super diversity' (see Vertovec, 2007), requiring greater responsiveness to the socio-economic and cultural needs of a range of ethnic minority populations (see Scholten \& Holzhacker, 2009). Equally, diasporas face challenges with their own integration and participation, and seek to influence policy priorities and the choices of host coun- try governments, including municipal government. Some challenges faced by diasporas include legal rights for different categories of migrants, social exclusion, and possible lack of recognition of their group as deserving of particular policy attention. In the Dutch context, minority groups tend to feature as actors in integration and participation policies in relation to their size or perceptions of the specific group as 'problematic.' Examples include large minorities with a history of Dutch colonisation, like the Surinamese and Antilleans who immigrated from the 1980s (Rath, 1999) and Turkish and Moroccans, large groups who arrived from the 1960s on- 
wards (Bosma, 2012). Sub-Saharan Africans, estimated as 241,644 people in the Netherlands in 2018 (Central Bureau of Statistics [CBS], 2019) remain less visible in policy prioritisation than these other groups of migrants. Most Sub-Sahara African diasporas arrived in the late 1980 s and early 1990s. Many were refugees driven by conflicts and authoritarian regimes; others were migrant workers. Many later arrivals came for higher studies, for family reunification, or to escape poor economic conditions in their home countries (Ong'ayo, 2019).

In this article, the term diaspora is used as a descriptive and analytical category (Sheffer, 2003) to understand the self-identification by "ethnic minority groups of migrant origin residing in host countries" (Vertovec, 1999, p. 1). This self-identification linked to multiple identities and layers of belonging is influenced by ties to the countries of origin and diaspora experiences in countries of residence where members of the diaspora have either acquired or seek to acquire legal residency and sometimes citizenship. The citizenship question is central to understanding how diasporas relate to host municipalities, and the rights they can exercise collectively as actors, individually, and through their organisations. Shared experiences and shared diasporic identities can be tools for mobilisation, and diasporic self-identification intersects with citizenship status, both being central to understanding the nature of diasporas' engagement with host country institution and policy makers in pursuit of common goals.

Citizenship, whether bound to the nation-state or denationalised and deterritorialised, as transnational, remains highly contested (Bauböck, 2006). In this article, I adopt a plural conception of citizenship to account for new categories of citizenship and belonging that seem to be emerging (Wotherspoon, 2018). This approach draws on Bauböck's (2018, p. 9) description of democratic pluralism as having two sides, involving both an "internal plurality of interests, identities and political, moral and religious ideas and [an] external plurality of political communities." A pluralist theory of citizenship as espoused by Bauböck (2018) succinctly captures the reality of diasporas' cross-border connections that tend to inform their construction of identity and the extension of their sense of belonging beyond a single nation state. The pluralist theory also acknowledges diasporas' multiple layers of belonging, attachments, and loyalties within the countries of residence and origin and how these impact on their citizenship and rights. Despite these multiple identities and layers of belonging, research on diasporas suggests they remain strongly connected to their host cities, which many consider 'home' alongside their original 'homeland' (Blunt \& Bonnerjee, 2013, p. 221). For this reason, different forms of citizenship or denial of citizenship rights will affect diaspora participation in relation to how they negotiate the terms of their inclusion and exclusion when it comes to the 'right to have rights' in the first place. In relation to situations where citizenship is bounded by formal membership of a state, rights enjoyed within a democratic polity can provide the openings needed for diasporic self-organising and collective action, aimed at making collective claims and influencing policies that affect the diaspora. In the case of the sub-Saharan African diasporas in The Hague, their collective organising is mainly geared towards addressing challenges around legal status, family reunion, Dutch language skills for newcomers and old timers, access to education and labour markets, and access to essential public services. For the African diasporas, selforganising through informal interventions has provided crucial platforms for securing their rights and having their interests heard. Using their civic agency, these diasporas have sought to link their own initiatives with more formal processes initiated by The Hague municipal institutions, in order to secure their rights, both as residents and citizens.

This article addresses a central question, namely to what extent collective initiatives by Sub-Saharan African diasporic groups in The Hague can promote more inclusive policy-making capable of addressing some of the key challenges facing these communities as well as the municipality. Even though most of these diasporic collective initiatives are informal, they offer useful models for thinking of more inclusive ways of addressing contemporary challenges posed by international migration and 'super-diverse' cities in host countries like the Netherlands. The article is based on fieldwork undertaken from 2015 to 2017 in The Hague, a city that profiles itself as an international city and the city of 'Justice and Peace.' Around one quarter of the city's population is composed of persons of migrant background, half of these 'non-Western' migrants. Sub-Sahara African diasporas are a vibrant part of the associational life and have their own formal organisations, and yet remain largely invisible in policies targeting minority groups in general. Data for this article was collected through semistructured interviews with 15 leaders of sub-Saharan African diaspora organisations, Dutch NGOs, and municipal departments involved with implementation of integration and participation policies in The Hague. It also drew on focus group discussions and participant observations during three diaspora community consultation events and three expert meetings involving representative of diaspora organisations, all held in The Hague. Especial attention is paid to the evidence from the three expert meetings, which illustrated how diasporic policy entrepreneurs enact their citizenship and deploy their civic agency when engaging policy makers from the host municipality. The first event, an expert consultation meeting held on August 4, 2017, was attended by some twenty representatives of different sub-Saharan diasporic organisations. The second meeting was attended by 21 people representing 20 organisations and 10 countries, and took place on August 24, 2017. The third event, an expert meeting held on September 27, 2017, also brought together African diaspora organisations, this time together with Dutch NGOs, policy officers from 
the municipality and representatives of the Ministry of Social Affairs. Total attendance was 57 people representing 23 organisations and 12 countries. Notes on these meetings were augmented by a review of policy documents from the various relevant institutions.

The research asked whether diaspora collective initiatives in joint policy-making can offer useful models for more inclusive ways of addressing challenges of social exclusion facing diasporas. It also focused on how diasporas respond to a constantly shifting political and policy environment, and the impact of municipal policy choices on how Sub-Sahara African diasporic communities organise and engage influence the policy agenda. For policy-makers and Dutch NGOs working with diaspora communities, their main concerns were how to design their own policies and activities targeting diasporic communities and how to anticipate political and policy shifts, in a context of a high degree of fragmentation among diasporic groups. What kind of policy frameworks would enable policy-makers to access minority groups, whose informal initiatives could play a significant role in the realization of integration and participation, a priority for NGOs and the municipality? The study used narrative analysis (Riessman, 1993) to give an account of identity constructions and claims made by African diasporic actors. By "turning narratives into an analytical causal explanation" (George \& Bennett, 2005, p. 211), insights were gained into how diasporic community leaders and policy makers described their visions towards engagement with one other. Participants' narratives during consultation and expert meetings were important for understanding perceptions and meanings attached to various experiences and to imagined solutions. The analysis focused on the interactional context to understand the underlying power dynamics, relations of trust and agendasetting in claimed or created spaces. To some extent, a sense of the agency of diasporic actors, or their lack of agency, emerged from how participants engaged with one another.

After this introduction, the second section examines some characteristics of Sub-Sahara African diasporas in The Hague municipality and their experiences with various integration and participation policies in the past.
The third section introduces conceptual reflections on the kinds of civic agency that drive sub-Saharan African diasporic collection action in this setting. The fourth section illustrates how collective diasporic initiatives by these groups attempt to negotiate more inclusive policymaking with The Hague municipality, and thus to find mutually agreed solutions to diasporic problems. The fifth section revisits notions of inclusive policy-making through the lens of civic agency to reflect on how subSaharan African diasporas in The Hague enact rights to social inclusion. I conclude by reflecting on citizenship rights, social inclusion, and the role of diasporic agency in these processes.

\section{Sub-Saharan African Communities in The Hague: Characteristics, Experiences, Civic Agency}

As mentioned earlier, sub-Saharan Africans remain one of the less visible minority groups in The Hague municipality when it comes to their formal participation in integration policies and programmes. According the Dutch CBS (2019), there were 49,987 Sub-Saharan Africans in The Hague municipality in 2018, which accounts for almost $10 \%$ of the total population (see Table 1 ). This makes up $9 \%$ of the population (CBS, 2019), while the second generation as shown in Table 1 constitute almost half of the Sub-Sahara African diasporas in The Hague (CBS, 2019). The Sub-Sahara African community is diverse and composed of persons from different countries and sub-groups from same country and have different immigration and integration histories and experiences.

Besides the expatriates and diplomats, in The Hague most Sub-Sahara Africans are persons that moved to the Netherlands because of conflict and political repression from countries like Somalia, Sudan, South Sudan, the Democratic Republic of Congo, Ethiopia, Eritrea, Burundi, Rwanda, and Uganda. In contrast with this, most Ghanaians, South Africans, Nigerians, Guineans, Cameroonians, and Kenyans fall broadly within the category of economic migrants, assumed to be largely voluntary, having arrived for further studies, for international jobs, and for family reunification. Even within single nationality groups, the diversity of status of Sub-

Table 1. Population backgrounds in The Hague municipality, 2010-2018. Source: CBS (2019).

\begin{tabular}{lcccr}
\hline & & $\mathbf{2 0 1 0}$ & $\mathbf{2 0 1 8}$ \\
\hline Categories & All & Second generation & All & Second generation \\
\hline Total & $\mathbf{4 8 8 , 5 5 3}$ & $\mathbf{9 5 , 1 6 4}$ & $\mathbf{5 3 2 , 5 6 1}$ & $\mathbf{1 1 5 , 2 9 3}$ \\
\hline Dutch & 253,860 & & 246,633 & \\
Migration background* & 234,693 & 95,164 & 285,928 & 115,293 \\
Non-western migration background* & 16,945 & 65,045 & 189,541 & 80,304 \\
Sub-Sahara Africa & 41,938 & 18,691 & 49,987 & 24,450 \\
\hline
\end{tabular}

Notes: * Terms derived from the definitions by the Dutch CBS, linked to categorisation based on the national origins of citizens. These categories are often used alongside the construct of allochthone used in reference to "repatriates (Indonesians), Ambonese (Malukans), Surinamese, Antillians, labour migrants (mostly Turkish and Moroccan), Chinese, refugees, students from the 'Third World' (mostly African and Asian countries)" (van Schie, 2018, pp. 78-79). 
Saharan African communities represents a considerable challenge both for the diasporas and for those policymakers who might wish for more inclusive forms of diasporic engagement with, and representation in, municipal affairs. Conversely, the vibrant associational life among Sub-Saharan Africans has led to various kinds of collective organizing across various social policy domains such as civic integration, health, education, culture, labour market participation and housing. Even so, direct engagement between Sub-Saharan African diasporic organisations and The Hague municipality remains quite limited, leaving these diasporic groups in a relatively disadvantaged position when it comes to accessing municipal policy-making processes and subsidies, for example.

It is perhaps instructive to examine how such diasporic groups seek to negotiate their space for participation in the context of increasingly assimilationist and restrictive immigration and integration discourses and policies in the Netherlands (Scholten \& Holzhacker, 2009). Cut-backs on subsidies tend to impact vulnerable diasporic communities since such policies reproduce exclusionary obstacles to a more generalised 'right to have rights' in the urban context (see Hintjens \& Kurian, 2019). The problem is especially acute among Sub-Saharan Africans who are undocumented, such as rejected asylum seekers and the homeless. Through the prism of citizenship, integration, and participation, it is useful to assess their status, how and they perform in Dutch language, in the labour market, and in other forms of urban citizen participation.

At the associational level, Sub-Saharan Africans in The Hague face material challenges of accessing community resources and working capital to fund their entrepreneurial initiatives. These social conditions inform several collective initiatives of the diasporas (their politics of action) and how they target their various needs (especially their politics of livelihoods; see Biekart \& Fowler, 2012; Fowler, 2009). As one participant the consultation meetings later observed:

Initiatives by the African diaspora organisations in The Hague already contribute to the well-being of their members but also contribute to the realisation of [the] municipality's policy goals....This role became critical with the arrival of newcomers during the recent refugee crisis. (Chairperson Eritrean Community, Personal communication, August 2, 2017)

One problem is the absence of an institutionalised diaspora engagement strategy that has compounded many of the challenges Sub-Saharan African diasporas face in their integration in The Hague. The hope remains that by meeting with wider stakeholders involved in integration, in participation, and in culture and social cohesionrelated policy fields, diasporic organisations can start to develop their own civic energy and professionalism, so they can also become more effectively engaged in dialogue with municipal-level policy-makers.

\section{Conceptual Reflections}

\subsection{Diaspora Engagement}

The Hague municipality has come under intense pressure to find solutions to these challenges through urban transformation in response to rising and complex international migration, and increased multiculturalism within the city (Duyvendak, Hendriks, \& van Niekerk, 2009). As the literature on diaspora engagement (Gamlen, 2008), makes clear, the onus is on initiatives by governments to reach out to diasporas. Whilst official policies acknowledge the value of remittances, they often lack clarity about how diasporas can become more involved in policy processes, finding common solutions to their own challenges by being formally invited to take part in civic engagement with the municipal authorities. A narrow definition of diaspora engagement denotes: "government overtures to diaspora communities through policy measures that establish formal channels for contacting and involving diaspora organisations in policy processes" (Ong'ayo, 2019, p. 77). Beyond the formal channels, however, the host society needs an understanding of what Francis Nyamnjoh (2012) refers to as the "conviviality" of diaspora groups. Those with different social, cultural, or political orientations co-exist (or 'convive') with each other, whilst realising their interdependence. Within subSaharan African diasporic communities such conviviality is largely informal. Yet through civic agency, even informal diaspora groupings collectively are demanding space to engage in policy deliberations and influence policy formulation (Gaventa, 2006). This leads us to a wider definition of diaspora engagement, that refers to both "the formal and informal interactions between diaspora organisations and policy-makers and key actors in within institutions and organisations involved in migrant-related policy fields" (Gaventa, 2006).

The proper role of diaspora participation in integration processes has become a major policy debate in the Netherlands in the past couple of decades (Penninx \& van Heelsum, 2004), with a heavy emphasis on migrants' own responsibility in the integration process. Other factors can be just as critical for diasporic integration and participation, beyond their own motivations and aspirations, such as their legal status and residency rights, the openness or restrictions of the national and urban policy environment, the labour market, social welfare entitlements, and wider socio-economic conditions (Ong'ayo, 2019). These conditions are obviously connected with questions of citizenship and belonging, and touch on law and rights, including the right to political and civic participation (Bauböck, 2006; Bloemraad, Korteweg, \& Yurdakul, 2008). Enactment of citizenship by diasporic organisation usually has social, economic, and cultural dimensions (Isin, 2013, 2017), and at municipal level involves diasporas engaging in collective organising to secure and defend their social and other urban policies that affect them. Whilst it is the agency of diasporic 
groups that shapes their engagement with municipal institutions and their participation in various urban public spaces, civic agency requires the municipality to be open to such initiatives of engagement by diasporas.

\subsection{Civic Agency}

The ability of diasporas to engage with policy-makers at different levels is a reflection of their degree of agency and of how they enact both individual and collective strategies to improve their own precarious living conditions. By adopting a civic agency perspective on change (see Biekart \& Fowler, 2012; Fowler, 2009), we focus on the strategies of the diaspora without losing sight of the responsibilities of municipalities like The Hague (Bakewell, 2010). Ultimately, civic agency can be described as the driving force that originates in "people's energy and imagination," in the diaspora but also in the municipality (Biekart \& Fowler, 2012, p. 181).

The concept of agency as used in diaspora studies is very broad, involving "the meanings held and practices conducted by social actors" (Vertovec, 1997, p. 24). In the case of the diasporas, they attach various values and meanings to collective actions both in the country of residence and in the country of origin (see Ong'ayo, 2019; Vertovec, 1997). Drawing on Vertovec's view, agency can be used to characterize the ability of diasporas to construct and reconstruct narratives around identity and create spaces for negotiations about the various aspects of diasporic experiences (Ong'ayo, 2019). Examples include narratives about belonging, demands for space and recognition, decision-making around migration policies, engagement in collective organising, and cooperation with government institutions around socio-economic and political challenges that diasporic groups encounter (Ong'ayo, 2019).

As described by Biekart and Fowler (2012, p. 182) civic agency is a "type of action that involves two core values: a concern for the whole-at whatever scale is appropriate-and respect for the many differences between people and groups that a society contains." Applied to diaspora collective organising, a civic agency lens points to the importance of understanding change beyond what Biekart and Fowler call the 'excluding view' of socio-political processes confined by a 'sector' concept of (civil) society as limited to a 'citizen view' among others (Biekart \& Fowler, 2012, p. 181). Drawing on the described principles of civic agency, diaspora collective organising as part of civil society initiatives demonstrate the enactment of citizenship through demands of space for their voices and to participate in the new society. They aim to engage The Hague municipality to help address their social exclusion, subverting hierarchies of citizenship and belonging, and to secure the 'right to have rights.'

\section{Diaspora Collective Action: Cooperation with the Municipality}

In the Dutch context, immigrant integration and participation policies derive from national integration policies and from specific experiences in 'model' municipalities. Diasporas respond to these policies by cooperating with the municipalities through a mix of top-down, bottom-up, and iterative approaches. At the municipal level, there are policies that have direct links to the status of the diasporas, their organisations, and interests (see Box 1). The main policy fields-such as youth, health, employment, and investment require civic integration and participation. Moreover, they should embrace the principle of diversity, which aims to secure "involvement of different groups and includes emancipation, inclusion and social cohesion" among its goals (Ong'ayo, 2019, p. 153).

Sub-Saharan African diasporas seek to address the problems they face through collective organising. Box 1 highlights some of these problems, including access to public services such as health for refugees, youth and education for newcomers, and non-recognition of qualifications from countries of origin, which denies many old timers the opportunity to access the labour market. Others find it difficult to access public utilities such as sports facilities, especially the newly arrived refugees with limited language skills, or undocumented people who are unable to obtain the ID card required to access municipal sports centres and swimming pools. Vulnerabilities generated by these requirements can lead to informal arrangements to address emergencies, such as health emergencies, extreme poverty and homelessness, legal problems, or educational exclusions. Municipal departments do provide some of these services. However, some diasporic groups may lack not information as such, but familiarity with Dutch institutional and policy environments where the relevant services can be accessed.

Box 1. Policy areas of interest to the African diaspora communities and organisations. Source: Adapted from Ong'ayo (2019).

- Youth, youth health, education, and internships;

- Health care and elderly care;

- Labour market participation (newcomers and highly educated people with language deficits);

- Integration of newcomers (new asylum seekers);

- Multicultural exchange;

- Exchange of information about investment opportunities in the countries of origin. 
From a policy-making perspective, the Dutch liberal democratic political system is sufficiently decentralised to provide an overall environment in which non-state actors can engage in the policy process to some extent (Norglo, Goris, Lie, \& Ong'ayo, 2016; Ong'ayo, 2019). At municipal level, residents and citizens have opportunities to place issue on the municipality's policy agenda through their own initiative (either individually or collectively). As part of the general public-and as consulted minorities-diasporas can thus take part in influencing municipal decision-making processes through referenda, hearings, council committee meetings, and public meetings in which the municipal staff explain their plans and invite feedback (Ong'ayo, 2019, p. 69).

The African community and diaspora organisations in The Hague opted for a broad form of civic engagement based on the priority of social inclusion (Wotherspoon, 2018). An illustration of this is their project entitled "African Community-Dialogue and Cooperation with the Municipality." This project sought to bring different African diaspora communities together in one inclusive platform, preserving their diversity whilst emphasising their common points and strengths. The strategy has been to act jointly in their dialogue with The Hague municipality, so as to have a common voice on policies affecting all African diasporas, across nationalities, citizenship status, and migration experiences. Such recognition of common ground, in diversity, underscores how diasporic civic agency has drawn from the cumulative energy, imagination, and creativity generated by a common diaspora platform in the city.

As pointed out by one community leader, "lack of support for the African community is an obstacle to their active participation and contribution to the Dutch society" (Chairperson Kumasi Youth Association, Personal communication, The Hague, June 26, 2015). Unfortunately, in recent years, municipal support for consultations of this kind has dwindled as austerity measures cut into local social programmes in The Hague. Diasporic organisations that have relied on subsidies have had to cut their services to members, whilst African diasporas remain largely invisible under current diversity policy.

The Sub-Sahara African diaspora organisations often focus on those members of the community that may be the most difficult for municipal interventions to reach. This important bridging role complements services organized formally through the municipality, and for The Hague municipality, it is vital to understand how diasporic organizations work with members and clients, informally as well as formally. This could make the municipality more aware of the kinds of challenges diaspora organisations face in their respective communities (Policy adviser, Department of Education, Culture and Welfare [OCW], Personal communication, The Hague, January 30, 2017). By the same token, it is just as important for subSaharan African diaspora organisations in The Hague to gain insights into the objectives and working methods of their municipality.
Following agreement on the significant role a common position could play in influencing the municipal policy agenda, the African Community Initiative Group in The Hague brought various African communities together under one single platform. Several meetings were organized to explore the possibility of using this platform to enable diasporic African actors and organisations to identify common problems. They could then work in collaboration with municipal departments and institutions on finding common solutions. The process was facilitated by the Participation Emancipation Professionals programme of the municipality in 2015 , and went parallel to outreach initiatives within the community. These 'expert meetings' became strategic response to diaspora fragmentation. The term 'expert' was chosen to address contestations about the expertise, skills, and experiences within the community and the donor narratives about capacity building. As noted by a community leader from the Kenyan community:

If we want to be taken seriously and change perceptions about migrants in terms of capabilities, we must do things differently.....It is about seeking own solutions with external support as complimentary....We organise these activities based on our strengths including experience, knowledge, and expertise in many fields. (Focus Group Discussion, August 4, 2017)

During an expert consultation meeting on August 4, 2017, Sub-Sahara African community leaders in The Hague discussed challenges experienced by different organisations (see Table 2). The consultation meeting focused on mapping themes, activities, and challenges facing organisations and communities where they work. The exchanges during this meeting sought to find convergences and commonalities that will serve as a basis for a joint platform. This meeting dealt with perceptions, meaning and real experiences, the diversity and fragmentation question as challenges to joint diaspora initiatives and a common stand when engaging with policy makers. The outcome of the consultation process led to a proposal for a pre-expert meeting targeting more than 40 organisations within the Sub-Sahara African diaspora community in The Hague to continue with the exchange sharing of experiences about their respective challenges, opportunities and solutions. This suggestion was based on practical experiences, knowledge of the political, policy, and institutional context by leaders from various country of origin communities. As outlined in Table 2, the preexpert meeting as a broad consultation process had specific objectives that recognise the diversity of interests and challenges within the diaspora communities.

The pre-expert meeting on August 24, 2017, as a platform can be argued to have served as a created space for collective enactment of citizenship and securing of rights. This can be noted in the framework for engagement and participation, interaction with policy-makers on jointly agreed terms, jointly identified issues of impor- 
Table 2. Objectives of consultative meetings. Source: Focus Group Discussions, August 4 and 24, and September $21,2017$.

\begin{tabular}{|c|c|c|}
\hline $\begin{array}{l}\text { Expert consultation meeting: } \\
\text { August 4, } 2017\end{array}$ & $\begin{array}{l}\text { Pre-expert meeting: } \\
\text { August 24, } 2017\end{array}$ & $\begin{array}{l}\text { Expert meeting: } \\
\text { September 21, } 2017\end{array}$ \\
\hline $\begin{array}{l}\text { 1. Mapping out challenges facing the } \\
\text { wider community (individuals and } \\
\text { organisations), through sharing } \\
\text { experiences and exchange of } \\
\text { information; }\end{array}$ & $\begin{array}{l}\text { 1. Bringing together the different } \\
\text { African communities in The Hague } \\
\text { in a collective platform to connect } \\
\text { with policymakers and relevant } \\
\text { institutions within the municipality; }\end{array}$ & $\begin{array}{l}\text { 1. Policy-makers in the municipality to } \\
\text { directly acquaint themselves with } \\
\text { important organisations and } \\
\text { players from the African } \\
\text { community; }\end{array}$ \\
\hline $\begin{array}{l}\text { 2. Seeking a common understanding } \\
\text { on issues that affect the wider } \\
\text { community; }\end{array}$ & $\begin{array}{l}\text { 2. Establish a framework for } \\
\text { addressing challenges within the } \\
\text { African community and } \\
\text { municipality; }\end{array}$ & $\begin{array}{l}\text { 2. Share knowledge about how } \\
\text { different African organisations } \\
\text { address problems within their } \\
\text { communities; }\end{array}$ \\
\hline $\begin{array}{l}\text { 3. Reaching out to more organisations } \\
\text { for adequate representation and } \\
\text { inclusivity; }\end{array}$ & $\begin{array}{l}\text { 3. Establish a framework for exchange } \\
\text { between diaspora organisations; }\end{array}$ & $\begin{array}{l}\text { 3. Identify successful initiatives and } \\
\text { explore possibilities for scaling up; }\end{array}$ \\
\hline $\begin{array}{l}\text { 4. Giving mandate to a leadership that } \\
\text { facilitates the platform and present } \\
\text { a proposal to the municipality. }\end{array}$ & $\begin{array}{l}\text { 4. Explore how to harness existing } \\
\text { potentials within the African } \\
\text { community. }\end{array}$ & $\begin{array}{l}\text { 4. Exchange ideas on how informal } \\
\text { diaspora initiatives can be validated } \\
\text { and linked to formal processes. }\end{array}$ \\
\hline
\end{tabular}

tance to both parties, and recognition of the added-value and policy relevance of diaspora initiatives. However, for the realisation of such broad objectives, a mechanism for gathering information and building consensus within the community while taking on a strategic approach to dealing with the policy environment is required.

The expert meeting held on September 21, 2017 (see Box 2), served as a space for experience sharing and seeking common solutions. Conducted within a created space, the meeting was diaspora-led in terms of agenda setting and programme implementation. For example, participants comprised of the representatives of African diaspora organisations, welfare organisations, policy-makers in the municipality, and the ministry of social affairs engaged in facilitated discussions, presentation of case studies, small group discussions, and plenary sessions. This contrasts with participation in invited spaces where input in such processes are limited to select speakers.

Guided by the themes outlined in Box 2, participants did an exercise of mapping and matching of actors on the basis of their concrete activities which were visualised through PowerPoint presentations. They also examined the conditions under which diasporas function and their relationship with policy-makers. These thematic areas reflect the need for a deep understanding of the policy environment and politics that inform policy choices and effects on diaspora involvement in policy-making. Given the issues in Box 2, the success of diaspora initiatives is challenged by invisibility in policy considerations. The professionalism of diaspora organisations is not always fully recognised (Chairperson Foundation Women Initiative Network, Personal communication, September 21, 2017). This applies to experiences of the diaspora collective initiatives outside the formal processes as crucial for finding commonalities and convergences of interests and policy relevance of diaspora activities.

Validation of informal practices is relatively rare. Thus, within the diaspora communities, it is common practice to informally support new members in the integration process, on a voluntary basis (Penninx \& van Heelsum, 2004) as well as during emergencies involving social welfare, health, or finances (Ong'ayo, 2019). Most of this work is done by volunteers who often work alongside their diasporic engagement. Thus, one interviewee explained:

Many practical matters must be arranged often at night, past official working hours in institutions, with

Box 2. Expert meeting, September 21, 2017: Exchange, reflections, recognition, validation, and possible solutions. Source: Focus Group Discussion, September 21, 2017.

\footnotetext{
- Interface with the government;

- Professionalization and institutionalization;

- Validation of informal practices;

- Planning, resources and accountability;

- Data and information;

- Image and public relations;

- Lobbying and advocacy.
} 
many additional expenses....It is difficult for diaspora organisations to include these activities in their planning and budgeting....Volunteers are left with the feeling of not being recognized, yet such activities complement institutions working with newcomers. (Chairperson Stichting Gobez, Personal communication, September 21, 2017)

These initiatives highlight the importance of diaspora organisations in addressing issues around integration, representation, and livelihood questions linked to exclusion. This practical and timely assistance to refugee families, to those with housing problems, to those needing care or hospital treatment, and to those faced with bereavement, is often not costed for and less recognised as labour to be compensated.

\section{Diaspora Engagement: Inclusive Policy-Making amidst Unequal Power Relations}

Sub-Sahara African diasporas in The Hague acknowledge the complex political and policy environment in which they function, hence they resort to collective initiatives that target joint solutions involving major stakeholders. The shift towards joint solutions emanates from recognised competing interests of many policy entrepreneurs in policy processes (Kingdon, 2014). It also relates to the Dutch government's policy changes from focus on specific groups towards diversity. As noted by one respondent:

Policy-makers are confronted with the challenge of making policy that only fits the needs of specific groups....Collective initiatives focusing on inclusivity contribute to our cause and we want this model for improving the integration of African diasporas in The Hague. (Policy Officer Integration, OCW, Personal communication, April 24, 2016)

Because of the devolved system of governance and decision-making, municipalities in the Netherlands can address needs of citizens based on context-specific realities (see Kos, Maussen, \& Doomernik, 2016). This policy space as part of the local political opportunity structures (Ong'ayo, 2019) enables diasporas to develop working relations with policy-makers. Equally, decentralised decision-making and policy implementation allows diaspora organisations as part of the civil society to get involved in the co-implementation of social policies in the municipalities (Ong'ayo, 2019, p. 153).

Initiatives by Sub-Sahara African diaspora organisations in The Hague demonstrate how diasporas make use of political opportunity structures and policy windows to influence policy in different policy spaces. This include participation in invited spaces (Cornwall, 2002) where diasporas contribute in government-organised policy consultation processes and in claimed and/or created spaces (Gaventa, 2006) where diasporas present their concerns to policy-makers during self-organised events. Diasporas and policy-makers acknowledge the importance of legitimacy derived from the inclusive orientation of activities which fits with municipal's diversity policy. As reiterated by a policy advisor in The Hague municipality:

In our experience with migrant groups, we prefer to work with formations that are more inclusive in their structures and activity focus....This is essential for addressing the challenge of diaspora fragmentation during policy consultations that require group representation. (Policy Advisor Integration, OCW, Personal communication, April 24, 2016).

Deliberations during the diaspora-organised expert meeting on September 21, 2017, for instance, demonstrate that interactions and exchanges between diaspora leaders and policy-makers lead to recognition and validation. This iterates observations that claimed or created spaces by the diasporas through bottom-up and iterative initiatives can create policy windows for influencing agenda setting (see Kingdon, 2014; Ong'ayo, 2019).

Sub-Sahara African diaspora organisations in The Hague municipality make use of both invited and claimed spaces to influence policy, but their ability to do so depends on how they deploy their agency to maximise on the existing political opportunity structures and policy windows created through overtures by policy makers or their self-organising. Underlying this self-organising is the policy environment in which the diasporas function and seek to influence. Access to policy spaces whether invited or claimed face challenges with regards to contestation about representation, interests of groups and policy makers. The policy environment in which the Sub-Sahara African diaspora organisations operate in The Hague is comprised of a variety of actors (state and non-state) and policy entrepreneurs with diverse interests. These interests affect recognition and invitation, modes of operation and access, representation and participation, and the kind of influence a group can have.

The complexity about participation of Sub-Sahara African diaspora organisations in policy processes in The Hague municipality stem from their heterogeneity even though Sub-Sahara Africa or African community are terms used for mobilisation and engagement with policy makers. There is no African community but still, (SubSahara) Africa as an identity becomes a tool for mobilisation in relation and competition to other migrant groups with large and long presence in The Hague municipality such as the Surinamese, Turks, and Moroccans. The various Sub-Sahara African communities represented in the platform and joint initiatives are in themselves diverse and fragmented on the basis of cleavages such as ethnicity, religion, regionalism, and political affiliations (in the country of origin and in the Netherlands), organisational categories (Umbrella organisations, Hometown associations or Migrant Development NGOs; see Ong'ayo, 2019). This diversity and fragmentation generate contes- 
tations about value and meanings attached to issues presented to policy makers in terms of their relevance and importance but also on the questions of representation and legitimacy.

Power struggles round representation and inclusion linked to diversity is a challenge to the unity of diasporas and presentation of a common position. This is more challenging in the context of the shift from the more multiculturalist policies that subsidized ethnic organizations to the diversity policy which gives focus to initiatives that reach out many groups within the neighbourhoods and not specific communities (see Hoekstra, 2018; Ong'ayo, 2019). A recognition of these realities linked to past failures to make impact during policy consultations, informs the approach of a board consultative meeting guided by the principles of transparent conversations about interests, acceptance of plurality of world views informed by different experiences. Nonetheless, a likely, persistent challenge to this approach is the subsidy logic, which continues to capture the imagination of many diaspora organisations since they have not made the shift in line with new funding realities, namely reduction in funding for integration programmes and migrant activities and the overall shift toward diversity policy that focuses of inclusivity of initiatives.

Additional area of contestation around diaspora engagement and participation in policy processes also relate the interactions between diaspora and policy makers. Drawing on the observations made during the expert meeting on September 21, 2017, it can be argued that the interactions between diaspora actors and policy makers, constitute a constellation of different dimensions of power relations both in invited and claimed or created spaces. First, it relates to agenda a setting. In the invited spaces at the municipal level, the agenda of the meetings are often set in advance by policy makers as informed by the policy priority fields and politics of the day within the municipality. In such cases, the diasporas have less leverage even though their participation is based on recognition of the added-value of their initiatives within the community to policy goals. This is in contrast to consultations within the framework of Citizen Initiative (Burgerinitiatief) forums where diaspora officials present their views on problems, challenges and opportunities, which they seek to address with support from the municipal institutions (see Ong'ayo, 2019).

Second, the power relations between diaspora organisation and policy makers remains fluid in the sense that the two actors need each other. Due to the complementary nature of diaspora initiatives to the institu- tional efforts especially the interventions that target the needs of hard to reach groups, diaspora organisations have some strength in their relative weak position in relation to policy makers. Likewise, the power wielded by policy makers in terms of funds given to diaspora organisations and other welfare organisations might not be in question, but international migration brings together both global and local social process that generate challenges linked to urban transformation and multiculturalism in the municipalities (Duyvendak et al., 2009). These social dynamics require alternative forms of intervention that find resonance with diaspora collective initiatives. The expert meetings organised by the Sub-Sahara African diaspora organisations therefore demonstrate how diasporas strategically apply their agency by inviting policy makers from relevant institutions to participate in their own events in order to undertake lobbying and advocacy at a collective level (see Ong'ayo, 2019).

The recommendations made during the expert meeting of September 21, 2017 (Box 3) are an acknowledgement that diaspora initiatives take place in spaces shaped by complex institutional and policy frameworks. This complexity compels the diasporas to reorganize and seek contact with policy-makers in their own space. Such initiatives and process are largely influenced by civic agency of the diasporas, how they enact their citizenship, pursue the 'right to have rights,' and address situations of social exclusion.

The spaces created by diaspora organisations seem to be useful from a strategic point of view in terms of agenda setting and steering the deliberation processes, interactions within these created spaces goes hand in hand with the nature of the framework for engagement (scope, mandate, and legitimacy), process, presentation, and language. Linked these observations, the dynamics during the expert meeting of September 21, 2017, reveal that diasporas, have to learn the policy language to be able to put forward their concerns for consideration in the policy and perform in a professional manner to change perceptions about their competence, skills, and knowledge. Because of the informal nature of most diaspora initiatives, limited knowledge about these activities and non-recognition in the policy parlance obscure opportunities for recognition and validation of diaspora activities. These dynamics constitute an aspect of power relations concerning positionality (recipient and giver) and the knowledge that informs the design and production of policy and subsequent interventions on matters affecting diaspora communities. For instance, the prevailing perceptions about the limitations of these informal ini-

Box 3. Joint policy-making: Mapping diaspora and policy concerns. Source: Focus Group Discussion, September 21, 2017.

- Joint analysis of problems, target groups, and solutions;

- Overview of themes and actors, convergences, strengths, and weaknesses;

- Recognition, validation, visibility, policy relevance, and social value of diaspora initiatives;

- Resources for strengthening and scaling-up initiatives. 
tiatives from a policy point of view, inform the nature of relationship, and interactions between the diasporas policy makers and limited openness to creative solutions developed from within the diaspora communities. In this regard, translation of the ideas of the diaspora into relevant and recognisable policy proposals constitute an area of power relation and challenge in diaspora engagement and participation in policy processes.

The relations between diasporas and policy-makers takes place within a complex institutional environment and intersection of policy domains involving multiple actors with competing interests. Nonetheless, there is less divergence on issues of concern to the diasporas and municipality as reflected in the themes emerging from the expert meetings. Notable ones are language, integration and participation; access to the labour market; education; culture; health youth and sport. These themes match policies in different municipal departments (Municipality of The Hague, 2011) and politics behind them. However, major contestations are about citizenship and rights, multiple identities and layers of belonging, and diversity as described the literature on super-diversity (Vertovec, 2007) and changing discourses (Scholten \& Holzhacker, 2009). For diaspora organisations, the identified issues are products of a long deliberation process that sought consensus in understanding their experiences. The conditions captured by these themes determine diaspora integration, performing of citizenship (Isin, 2017), social exclusion (Kos et al., 2016; Wotherspoon, 2018), and the 'right to have rights.' They also relate to the well-being of the different categories of Sub-Sahara African diasporas, and how they seek to realise their aspirations within a 'win-win' framework. This 'win-win' framework relates to the benefits of the outcomes of collective initiatives to the diaspora organisations in terms of access to policy-making spaces, where they can channel their concerns about rights and space to influence agenda setting (see Ong'ayo, 2019). To policy makers, these diaspora collective initiatives contribute to the realisation of various social policies targeting integration and participation, public health, and social cohesion (Ong'ayo, 2016) through diaspora activities that complement the existing public services (see Ong'ayo, 2016, 2019).

The collective initiatives by the Sub-Sahara African diasporas in The Hague offer evidence of the praxis of civic agency in terms of how diasporas seek to create spaces for making claims and influencing policy agenda which starts with how they frame issues that matter to them. For example, shift towards the use of diaspora experiences, knowledge, skills, and expertise as a basis for taking the lead in steering the consultation and expert meetings, is a demonstration of civic agency in practice as diasporas create conditions they collectively imagine and want, and the terms for engaging with policy-makers. Their civic agency thus informs the choice, definition, and re-definition of topics to reflect meanings diasporas attach to these topics. This iterates the conceptualisa- tion of civic agency whereby collaboration is informed by "power in the foreground, about negotiating and forming relationships that further civic agency" (Biekart \& Fowler, 2012, p. 7).

\section{Conclusion}

This article considered the case of sub-Saharan African diasporas and how their civic agency sought to influence enacted citizenship initiatives aimed at more inclusive policy-making towards shared outcomes and common solutions with The Hague municipality. Collective initiatives helped to generate prospects for these diasporas to secure their rights and address conditions that led to social exclusion. If diasporic civic engagement is undertaken through initiatives that build on collectivelycreated spaces, informed by an understanding of individual and collective interests, these formal and informal initiatives can promote more participatory diasporic involvement in reciprocal and complementary decisionmaking at municipal level. Underlying this argument, based on observations during various policy consultation processes, is the principle of joint policy-making for finding common solutions.

These diaspora collective initiatives manifest the critical role of diasporas as bridge-builders and interlocutors, able to inject elements of complex diversity into urban transformations that respect the diasporic right to the city and to urban spaces and services. Central to the civic agency and energy of diasporas is their ability to tap into policy windows and prevailing political opportunity structures in the municipality in order to ensure their needs are better addressed. Their agency is linked to the politics of action and redistribution of resources that challenge conditions of social exclusion and destitution in the host municipality of The Hague.

For the diasporas, access to decision-making spaces, whether invited, claimed, or co-created, can expand the scope for enacting diasporic urban citizenship. This includes the 'right to have rights' by influencing agenda setting alongside other policy entrepreneurs from within and outside civil society. In this sense, civic agency operates at the intersection of diasporas' pursuit of influence and municipal strategies of inclusive policy-making and finding common solutions. Given the relative novelty of openings towards greater diaspora engagement, the processes involved require robust theorizing, especially given the complex local, national, and global environment in which diasporas are working to challenge their own prior conditions of social exclusion and invisibility to policy-makers working in the migration-related policy fields.

\section{Acknowledgments}

I wish to thank Kees Biekart and Helen Hintjens for initial feedback and the two anonymous reviewers for their useful comments. 


\section{Conflict of Interests}

The author declares no conflict of interests.

\section{References}

Bakewell, O. (2010). Some reflections on structure and agency in migration theory. Journal of Ethnic and Migration Studies, 36(10), 1689-1708.

Bauböck, R. (2006). Migration and citizenship legal status, rights and political participation. Amsterdam: Amsterdam University Press.

Bauböck, R. (2018). Democratic inclusion: A pluralist theory of citizenship. Manchester: Manchester University Press.

Biekart, K., \& Fowler, A. (2012). A civic agency perspective on change. Development, 55(2), 181-189.

Bloemraad, I., Korteweg, A., \& Yurdakul, G. (2008). Citizenship and immigration: Multiculturalism, assimilation, and challenges to the nation-state. Annual Review of Sociology, 34, 153-179.

Blunt, A., \& Bonnerjee, J. (2013). Home, city and diaspora: Anglo-Indian and Chinese attachments to Calcutta. Global Networks, 13(2), 220-240.

Bosma, U. (2012). Post-colonial immigrants and identity formations in the Netherlands. Amsterdam: Amsterdam University Press.

Central Bureau of Statistics. (2019). Bevolking; leeftijd, migratieachtergrond, geslacht en regio, 1 januari [Population; age, migration background, sex and region, 1 January]. Central Bureau of Statistics. Retrieved from https://opendata.cbs.nl/statline/\#/CBS/ $\mathrm{nl} /$ dataset/37713/table?fromstatweb

Cornwall, A. (2002). Making spaces, changing places: Situating participation in development (Institute of Development Studies Working Paper No. 170). Brighton: Institute of Development Studies.

Duyvendak, J., Hendriks, F., \& van Niekerk, C. M. (2009). City in sight: Dutch dealings with urban transformation. Amsterdam: NICIS-Amsterdam University Press.

Fowler, A. (2009). Civic agency. In H. Anheier \& S. Toepler (Eds.), International encyclopaedia of civil society (pp. 150-155). New York, NY: Springer.

Gamlen, A. (2008). Why engage diasporas (Working Paper No. 63). Oxford: Centre on Migration, Policy and Society, University of Oxford.

Gaventa, J. (2006). Finding the spaces for change: A power analysis. Institute of Development Studies Bulletin, 37(6), 23-33.

George, A. L., \& Bennett, A. (2005). Case studies and theory development in the social sciences. Cambridge, MA: MIT Press.

Hintjens, H., \& Kurian, R. (2019). Enacting citizenship and the right to the city: Towards inclusion through deepening democracy? Social Inclusion, 7(4), 71-78.

Hoekstra, M. S. (2018). Governing difference in the city: Urban imaginaries and the policy practice of migrant incorporation. Territory, Politics, Governance, 6(3), 362-380.

Isin, E. F. (2013). Claiming European citizenship. In E. Isin \& M. Saward (Eds.), Enacting European citizenship (pp. 19-46). Cambridge: Cambridge University Press.

Isin, E. F. (2017). Performative citizenship. In A. Shachar, R. Bauböck, I. Bloemraad, \& M. Vink (Eds.), The Oxford handbook of citizenship (pp. 500-523). Oxford: Oxford University Press.

Kingdon, J. W. (2014). Agendas, alternatives, and public policies (2nd ed.) Essex: Pearson Education Limited.

Kos, S., Maussen, M., \& Doomernik, J. (2016). Policies of exclusion and practices of inclusion: How municipal governments negotiate asylum policies in the Netherlands. Territory, Politics, Governance, 4(3), 354-374.

Municipality of The Hague. (2011). De Haagse participatiemaatschappij uitvoeringsprogramma welzijn 2011-2014 [The Hague participation society implementation program on welfare 2011-2014]. The Hague: Municipality of The Hague.

Norglo, B. E., Goris, M., Lie, R., \& Ong'ayo, A. O. (2016). The African diaspora's participation in policy-making concerning Africa. Diaspora Studies, 9(2), 83-99.

Nyamnjoh, F. B. (2012). Potted plants in greenhouses: A critical reflection on the resilience of colonial education in Africa. Journal of Asian and African Studies, 47(2), 129-154.

Ong'ayo, A. (2016). Diaspora organisations and their development potential: An analysis of Ghanaian diaspora organisations in the UK, Germany and Netherlands (Discussion Paper No. 200). Maastricht and Brussels: European Centre for Development Policy Management.

Ong'ayo, A. (2019). Diaspora organisations, transnational practices and development: Ghanaians in the Netherlands (Unpublished Doctoral dissertation). Tilburg University, Tilburg, the Netherlands.

Penninx, R., \& van Heelsum, A. (2004). Bondgenoot of spelbreker? Organisaties van immigranten en hun mogelijke rol in integratieprocessen [Ally or game breaker? Immigrant organizations and their possible role in integration processes]. Utrecht: FORUM.

Riessman, C. K. (1993). Narrative analysis. London and Newbury Park, CA: Sage.

Scholten, P., \& Holzhacker, R. (2009). Bonding, bridging and ethnic minorities in the Netherlands: Changing discourses in a changing nation. Nations and Nationalism, 15(1), 81-100.

Sheffer, G. (2003). Diaspora politics: At home abroad. Cambridge: Cambridge University Press.

van Schie, G. (2018). Origins: A history of race-ethnic categorisation in the Dutch governmental data ontology (1899-2018). Tijdschrift voor Mediageschiedenis, 21(2), 67-88.

Vertovec, S. (1997). Three meanings of 'diaspora,' exemplified among South Asian religions. Diaspora, 6(3), 277-299.

Vertovec, S. (1999). Conceiving and researching transna- 
tionalism. Ethnic and Racial Studies, 22(2), 445-462.

Vertovec, S. (2007). Super-diversity and its implications.

Ethnic and Racial Studies, 30(6), 1024-1054.
Wotherspoon, T. (2018). Migration, boundaries and differentiated citizenship: Contested frameworks for inclusion and exclusion. Social Inclusion, 6(3), 153-161.

\section{About the Author}

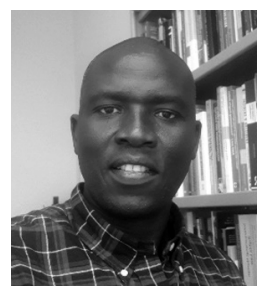

Antony Otieno Ong'ayo is a Researcher at the International Institute of Social Studies of Erasmus University. He holds a Bachelor's and a Master's degree in Political Science from Stockholm University and a PhD in Humanities (International Development) from Tilburg University. He is an Associate Researcher with Globalization, Accessibility, Innovation and Care (GAIC) and member of the Commission on Development Cooperation (COS) of the Advisory Council on Foreign Affairs (AIV) to the Dutch Government. Research interests include politics of development, migration and development, diaspora transnationalism, digital citizenship, and governance. 